\title{
Family farm business and access to rural development polices: a demographic perspective
}

\author{
Luca Bartoli and Marcello De Rosa
}

\author{
*Correspondence: bartoli@eco. \\ unicas.it \\ Department of economics and Law, \\ University of Cassino and Southern \\ Lazio, Via Folcara Cassino (Fr) \\ 03043, Italy
}

\begin{abstract}
This article aims to show the ability of family farms in obtaining funds from rural development policies. Under the hypothesis that family farms' characteristics influence their access to policies, the perspective of analysis is demographic. In the paper two demographic viewpoints are investigated, to emphasize the role of the family composition in fostering strategic farms' decisions: the localization in the life cycle and the presence of assistants. The empirical test is provided for an Italian region: the funds of rural policies gained by family farms are examined, divided up into the three main strategic axes of the rural development plan. The results of the analysis highlight some interesting differences between the two demographic perspectives; the presence of assistants influences a farm's strategic process and increases the access to rural policies. This induces normative consequences in terms of the possible articulation of policies aimed at sustaining family farms.
\end{abstract}

Keywords: Rural development policies; Family farm business

\section{Background}

The aim of this paper is to analyze funding strategies adopted by family farms with reference to rural development plans. More precisely, it looks into the influence of demographic variables on obtaining funds from the rural development policy: we define as "consumption of policy" the farm's ability to obtain funds from rural development policies.

A general characteristic of the agricultural sector in many European countries is the presence of an overlap between the productive and domestic spheres, that is farms' strategies depend on the family situations (Jervell 1999). According to Gasson et al. (1988), family farm businesses are related to situations where:
a) the principals are related by kinship or marriage,
b) business ownership is usually combined with managerial control, and
c) control is passed from one generation to another within the same family.

In this context, any boundary between productive and reproductive work in the farm household is artificial (Errington and Gasson 1993) and conditions farms' strategies and aptitude to invest: the number of family members and localization in the life cycle could be relevant variables of influence. In a lot of cases, demographic transition, either

C 2013 Bartoli and De Rosa; licensee Springer. This is an open access article distributed under the terms of the Creative Commons Attribution License (http://creativecommons.org/licenses/by/2.0), which permits unrestricted use, distribution, and reproduction in any medium, provided the original work is properly cited. 
vertical or oblique (Bergstrom 1996), is stimulated by policies aiming at favoring intergenerational transmission. Besides, other investments are necessary to maintain a farm's profitability and its persistence over time. In order to cope with an even more competitive scenario and to secure a family farm's resilience, a mix of strategies has to be carried out (Darnhofer 2010).

Recent rural development polices make a set of instruments available in order to sustain farm competitiveness and to diversify agricultural income. The possibility to obtain funds is influenced by a set of constraints which, in many cases, reduce the consumption of policies. In this situation, an interesting field of analysis is the influence of demographic variables in accessing rural policies.

After presenting a brief theoretical overview, the paper proposes an empirical test within an Italian region (Lazio), where the odds of gaining access to rural development policies will be examined through a logistic regression model. The paper sustains the hypothesis of differentiation in the access to policies, due to demographic factors in the composition of family farms.

As Offutt (2002) points out, since farm households are demonstrably diverse, analysts would seem obliged to investigate hypotheses about differential response and impact. One of these differences concerns demographic variables: family contexts are particularly favorable to set up a farm venture (Jervell 2011): an abundant economic literature has emphasised the strict connection between farm household strategies and style of farming (among others, Whatmore, 1994), by demonstrating the persistency of family farms (Sabbatini 2011). Their ability to survive over time witnesses the relevance of F-connection ${ }^{1}$ in fostering lower levels of transaction costs and a higher aptitude to adapt (Ben-Porath 1980; Pollack 1985; Corsi 2009).

Social approaches to this theme underline the relevance of non-profit decisions in maintaining farming activity (Kuehne et al. 2010). For example, some researchers emphasize the relevance of family identity in strengthening the links between the future and past family history (Burton, 2004). Furthermore, a sentimental attachment to the place (place dependence and place identity) reinforces the links between farmer and farming and delays the eventual decision to retire (Kuehne 2012). However, in many other cases financial constraints are determining factors, thus inducing the abandonment of activity. To avoid this, agricultural policy offers financial support to promote farm adjustments.

Some authors have recently stressed the role of the Common Agricultural Policy in preserving small farms (Koutsou et al. 2011), through the process of the functional repositioning of agriculture, as a result of deepening, broadening and regrounding, and through the creation of rural webs (van der Ploeg and Marsden 2008).

As a matter of fact, family farms are expected to play an important role even in the new scenario of "modern rurality" designed within the rural development policies (Abdelmalek, 2000). Family units are requested to face competitive challenges through the definition of farm strategies, which are generally overlapping with family strategies (Caillavet et al. 2005; Abdel 1997). In this context a relevant subject of analysis is related to the capabilities of gaining access to rural development policies, which contain a set of measures to sustain either farm competitiveness or diversification, along sectorial or territorial trajectories of development. This ability could be decreased both on the supply and the demand side. From the supply standpoint, a large literature taking origin from Downs (1957) work has demonstrated that deviations emerge in a context of 
public choice. As far as demand is concerned, collective action theories evidence the relevance of pressure groups in conditioning policy decisions (Olson 1965; Becker 1983) ${ }^{2}$.

The impacts of agricultural policies on farms' structural adjustments are analysed also within agent-based models (Balmann 1997; Albisser and Lehmann 2007; Balmann et al. 2003), which endogenise the importance of psychological and social factors which interfere in the farmer's strategy definition. They are considered to be a useful tool to evaluate agricultural policy impact (Berger 2001; Happe 2004). More recent studies have emphasized the relevance of territory, social capital and socioeconomic farm characteristics in obtaining access to rural policies and fostering local rural development (Sabbatini, 2008; Meert et al., 2005; Marotta, 2007; Casieri et al., 2010). The inclination to adopt rural policy, that is to receive subsidies within the rural development framework, is variable and could depend on socio-demographic characteristics of the farm: family size, presence of young farmers and localization in the life cycle are influencing factors that should be examined in depth. As a matter of fact, consuming policy is a costly activity in terms of time spending and opportunity costs; in addition, informational asymmetries represent an important barrier to access. To overcome these obstacles, farmers have to improve their attention: neo-Austrian perspectives permit to get a better comprehension of the decision processes through the concept of entrepreneurial alertness (Kirzner 1973).

In the Kirznerian perspective, the entrepreneur is characterised by the aim to increase profits: to this end, he or she must pay attention to opportunities. Kirzner (1997) makes reference to the concept of alertness to summarize the entrepreneur's aptitude to take advantage of opportunities. Access to rural development policies becomes a way to support farm adjustments.

The decision about consuming or not and about what measures are better to adopt could be influenced by demographic variables. As thoroughly demonstrated in literature, demographic variables are commonly recognized as explanatory factors influencing farm strategies: family composition and localization in the life cycle are determinants of different paths of development. What does the term demographic really mean? Should one refer to all the members of the family, or to the members effectively employed on the farm? Are there any differences if considering one or the other typology of family farms? Our paper sets in this context and aims at analysing the influence of demographic variables on the farm's decision to adopt rural policies. By proposing a two-way classification of family farms, the hypothesis under analysis is that possible differences in the access to rural development policies could emerge. The research is conducted through interdisciplinary approaches which privilege a demographic perspective of analysis, where the fundamental elements are related to farm family traits.

To this end, after a brief methodological note our analysis proposes an empirical test of the access to rural policies, within an Italian region (Lazio). The hypothesis under study is that family composition influences the consumption of policies.

\section{Methods}

Family farms are the object of our analysis, marked out by three methodological steps. The first one concerns the demographic classification of family farms from a double perspective: 
a. one is essentially based on demographic variables: it considers just age and the size of family as relevant aspects to be analysed;

b. the other classification takes into account farm activity and the composition of family work.

The first classification makes reference to previous publications (Bartoli and De Rosa 2007), where family composition and its localization in the life cycle are the key variables. The second one emphasizes the role of farm's assistants ${ }^{3}$ exclusively employed within the farm or not. Due to the different perspective, the family cycle is a bit different: in the demographic typology, the young phase threshold is 35 years. Otherwise, in the second typology the age of reference is 40 years, because it is the threshold to gain access to rural development policies for generational change ${ }^{4}$.

Of course, this difference could raise possible dissimilarities in the total amount of young farms ${ }^{5}$.

I typology

$-<35$ years

- 35-64 years

$->65$ years

II typology

$-<40$ years

- 40-64 years

$->65$ years

Accordingly, the following typologies of farms will be analyzed (Table 1):

The differences between the two types of family farms concern a possible different degree of involvement of family members: in the first type, family members may not be involved in the farm business and may have interests in working outside the farm; in the second case the decision process stems from people who may not share similar objectives but who are involved in farming activity; they participate and cooperate to define the farm's strategy.

The second methodological step tries to link family types and access to the rural development policy, by focusing attention on the consumption of rural development policies in the region of Lazio (Italy): the measures under observation belongs to the three main axes of regional rural program:

1. competitiveness of the agricultural sector;

2. environment and landscape;

3. quality of life and diversification in rural areas.

Information and data are taken from the questionnaire of the last census of Italian agriculture, at Section 1, point $7^{6}$. As a consequence, our analysis is necessarily partial: indeed, census data take as reference year 2010, so this covers a maximum of two/three years compared to the duration of the rural development programme (7 years). 
Table 1 The two considered typologies

\begin{tabular}{lc}
\hline I typology & Il typology \\
\hline Only farmer & Young farmer and a not young assistant \\
- young & $-\mathrm{p} / \mathrm{e}$ \\
- mature & $-\mathrm{np}$ \\
- older & Young farmers without assistant \\
Childless couples & \\
- young & \\
- mature & \\
- older & Mature farmer and a young assistant \\
Couples with children & $-\mathrm{p} / \mathrm{e}$ \\
- young & $-\mathrm{np}$ \\
- mature & \\
- older & Mature farmers without assistant \\
Extended families and other & Older farmer and a young assistant \\
& $-\mathrm{p} / \mathrm{e}$ \\
& $-\mathrm{np}$ \\
& Older farmers without assistant \\
\end{tabular}

$\mathrm{p}=$ prevailingly employed in the farm.

$\mathrm{np}=$ not prevailingly employed in the farm.

$\mathrm{e}=$ exclusively employed in the farm.

The third methodological step aims at testing the (eventual) higher probability to gain access to the rural development policy on the basis of type of family farm. To this end, we apply a binomial logistic regression with categorical explanatory variables: more precisely the explanatory variables were divided into $n-1$ dichotomous variables (Knoke and Burke 1980). This methodology is based on the assumption that the probability for the dependent variable $\mathrm{Y}$ to be equal to 1 is a function of the considered explanatory variables $^{7}$. Since these variables are polichotomous (belonging to one of the types of that particular issue), they are treated as if each mode is in turn an explanatory dichotomous variable that helps to increase or decrease the success probability of the dependent variable. The function studied by the model is the following:

$$
Y=\log i t(x)=\ln [o d d s(x)]=\beta_{0}+\beta_{1} x_{1}+\ldots \beta_{k} x_{k}
$$

where $\mathrm{Y}$ is the dichotomous dependent variable "adoption of policies" that equals 1 for farms that have gained funds and 0 for those that have not obtained any fund. The estimation function measures the success probability related to each modality of the independent variable. For each modality, the probability to get access to funds is estimated with respect to a defined modality.

The model is based on the concept that the logit is a linear function of each regressor's parameters. In order to distinguish the two different demographic perspectives, two different models will be estimated for each type of family farms.

\section{Results and discussion}

The recent publication of the Italian census of agriculture reveals some structural adjustments but confirms two key factors characterising the agriculture of Lazio region. 
First of all, the presence of a fragmented structure of family farms can be observed: even though the number of family farms has reduced by $41 \%$, with respect to the previous census in 2000, in 2010 96\% of all farms are directly managed by farmers, i.e., an increase of two percentage points. The second aspect of interest is the low presence of young farmers: Table 2 illustrates the prevalence of mature and older farms with respect to the younger ones. Less than $9 \%$ of farms is managed by younger farmers ( $<40$ years); the share sensibly reduces in farms managed by farmers under 30 . In the perspective of our analysis this contributes to fix the agricultural sector and impede processes of structural adjustment.

In what follows, we investigate the role of policies in fostering farm transformation and the eventual differences on the basis of demographic variables.

\section{Consumption on the basis of family characteristics}

An important result of our analysis confirms previous studies on limited access to rural polices on behalf of Italian farms (Bartoli and De Rosa, 2011). Very small percentages of farms gain access to funds; in this context some differences on the basis of demographic variables emerge. Most of the first type of family farms does not use rural policy measures to sustain farm growth (Table 3). On average, $95 \%$ of farms have not used any measure of the rural development plan. However, the presence of young farmers raises the percentage of policy consumption, but within the group of young farmers different aptitudes stand out. Single young farmers display the highest percentage of access to policies (14.4\%). On the other hand, moving to other young families (childless and couple with children), the percentages decrease, even if they remain above the average (respectively $9 \%$ and $10 \%$ ). In the remaining family farms, statistically significant results are found in extended families and partially in single mature farms. In the other typologies a systematic lower level of access is evident, above all in the childless

Table 2 Age of farm entrepreneur (\%)

\begin{tabular}{lll}
\hline$<20$ years & $\mathbf{2 0 1 0}$ & $\mathbf{2 0 0 0}$ \\
$20-24$ years & 0.04 & 0.15 \\
$25-29$ years & 0.52 & 0.36 \\
$30-34$ years & 1.35 & 1.10 \\
$35-39$ years & 2.50 & 2.65 \\
$40-44$ years & 4.46 & 4.70 \\
$45-49$ years & 6.83 & 7.16 \\
$50-54$ years & 9.22 & 9.61 \\
$55-59$ years & 11.06 & 13.00 \\
$60-64$ years & 12.60 & 11.08 \\
$65-69$ years & 14.35 & 13.24 \\
$70-74$ years & 10.27 & 12.58 \\
$75-79$ years & 10.82 & 11.12 \\
$>80$ years & 8.10 & 8.01 \\
Total & 7.89 & 5.24 \\
\hline
\end{tabular}

Source: Region Lazio, $6^{\text {th }}$ Italian census of agriculture. 
Table 3 Access to rural policies in the first type of family farms

\begin{tabular}{|c|c|c|c|}
\hline \multirow[t]{2}{*}{ I family type } & \multicolumn{2}{|c|}{ Total consumption } & \multirow[t]{2}{*}{ Total } \\
\hline & NO & YES & \\
\hline Only farmer $Y$ & 1,466 & 246 & 1,712 \\
\hline Only farmer M & 14,603 & 952 & 15,555 \\
\hline Only farmer 0 & 12,154 & 589 & 12,743 \\
\hline Childless couple Y & 780 & 77 & 857 \\
\hline Childless couple M & 18,694 & 800 & 19,494 \\
\hline Childless couple $O$ & 11,115 & 367 & 11,482 \\
\hline Couple with children Y & 753 & 89 & 842 \\
\hline Couple with children $M$ & 19,830 & 1,135 & 20,965 \\
\hline Couple with children $O$ & 3,638 & 146 & 3,784 \\
\hline Extended families and other & 13,516 & 1,178 & 14,694 \\
\hline Total & 96,549 & 5,579 & 102,128 \\
\hline \multirow[t]{2}{*}{$\%$} & \multicolumn{2}{|c|}{ Total consumption } & \multirow[t]{2}{*}{ Total } \\
\hline & NO & YES & \\
\hline Only farmer $Y$ & 85.6 & 14.4 & 100.0 \\
\hline Only farmer M & 93.9 & 6.1 & 100.0 \\
\hline Only farmer 0 & 95.4 & 4.6 & 100.0 \\
\hline Childless couple Y & 91.0 & 9.0 & 100.0 \\
\hline Childless couple M & 95.9 & 4.1 & 100.0 \\
\hline Childless couple $O$ & 96.8 & 3.2 & 100.0 \\
\hline Couple with children Y & 89.4 & 10.6 & 100.0 \\
\hline Couple with children M & 94.6 & 5.4 & 100.0 \\
\hline Couple with children $O$ & 96.1 & 3.9 & 100.0 \\
\hline Extended families and other & 92.0 & 8.0 & 100.0 \\
\hline Total & 94.5 & 5.5 & 100.0 \\
\hline
\end{tabular}

Source: data processed from the database of Region Lazio.

older families: in this case the reduced propensity to consume policies is evidently due to the limited perspective of vertical transmission.

The second typology highlights a similar composition in the access to polices, which points out a higher percentage in the case of young families: but, in this case, a significant contribution to the phenomenon is given by the presence/absence of an exclusive assistant (Table 4). In young families with an exclusively employed (even not young) assistant, the percentage of access is relevant: $18.3 \%$ of farms have obtained funds. In the other two cases of young family farms the shares of access are certainly statistically significant, but lower (about 11\%). The transition toward older stages of the life cycle reduces the access to rural policies, above all in the presence of assistants non-exclusively employed in the farm. The role of assistants seems relevant in obtaining access to funds, even when this role is decreasing in older phases of the life cycle.

By comparing the two types of family farms we can add other considerations: in each phase of life cycle, the presence of an assistant (either prevalent or exclusive) enhances the access for funds and gives a strong contribution to decision process. In order to validate previous results, an econometric model is proposed in the next paragraph. 
Table 4 Access to rural policies in the second type of family farms

\begin{tabular}{|c|c|c|c|}
\hline \multirow[t]{2}{*}{ II family type } & \multicolumn{2}{|c|}{ Total consumption } & \multirow[t]{2}{*}{ Total } \\
\hline & NO & YES & \\
\hline Young farmer and a not young assistant p/e & 1,669 & 374 & 2,043 \\
\hline Young farmer and a not young assistant $n p$ & 641 & 84 & 725 \\
\hline Young farmer without assistant & 6,483 & 840 & 7,323 \\
\hline Mature farmer and a young assistant p/e & 4,754 & 382 & 5,136 \\
\hline Mature farmer and a young assistant np & 2,018 & 109 & 2,127 \\
\hline Mature farmer without assistant & 44,461 & 2,264 & 46,725 \\
\hline Older farmer and a young assistant p/e & 1,240 & 86 & 1,326 \\
\hline Older farmer and a young assistant $n p$ & 894 & 60 & 954 \\
\hline Older farmer without assistant & 34,389 & 1,380 & 35,769 \\
\hline Total & 96,549 & 5,579 & 102,128 \\
\hline \multirow[t]{2}{*}{$\%$} & \multicolumn{2}{|c|}{ Total consumption } & \multirow[t]{2}{*}{ Total } \\
\hline & NO & YES & \\
\hline Young farmer and a not young assistant p/e & 81.7 & 18.3 & 100.0 \\
\hline Young farmer and a not young assistant $n p$ & 88.4 & 11.6 & 100.0 \\
\hline Young farmer without assistant & 88.5 & 11.5 & 100.0 \\
\hline Mature farmer and a young assistant p/e & 92.6 & 7.4 & 100.0 \\
\hline Mature farmer and a young assistant $n p$ & 94.9 & 5.1 & 100.0 \\
\hline Mature farmer without assistant & 95.2 & 4.8 & 100.0 \\
\hline Older farmer and a young assistant ple & 93.5 & 6.5 & 100.0 \\
\hline Older farmer and a young assistant $n p$ & 93.7 & 6.3 & 100.0 \\
\hline Older farmer without assistant & 96.1 & 3.9 & 100.0 \\
\hline Total & 94.5 & 5.5 & 100.0 \\
\hline
\end{tabular}

Source: data processed from the database of Region Lazio.

\section{The logistic model}

As highlighted in Table 5, the results of the logistic regression model are acceptable and statistically significant, even if the pseudo R-squared does not have a high value. From the table we can reject the zero value hypothesis. Thereby, family farms typology influences the access to rural development policies.

Tables 6 and 7 shows the results obtained from the model, comparing the likelihood of access among the two typologies of family farms. Demographic variables introduce further elements of reflection with respect to previous analysis: the logistic regression highlights a strong correlation between localization in the life cycle and access to policies. Family farms in which the entrepreneur is a young farmer are more probable to gain access to policies; in mature and elderly families an inverse correlation with the access to rural policies is evident. The more a family farm is in the advanced stage of the life cycle the less will be the probability to consume policy. In the Kirznerian perspective, single young farmers are more alert and determined to invest and to exploit the opportunities, with respect to young couples with or without children. In relation to extended families the probability for a single young farmer is $91 \%$ higher (Table 7 ), while, in young couples the same probability is $13 \%$ higher and in couples with children it is $35 \%$ higher: the presence of children increases the access to policies, presumably to increase the ability of the next generation to take over the farm. On the other hand, 
Table 5 Zero value global hypothesis test

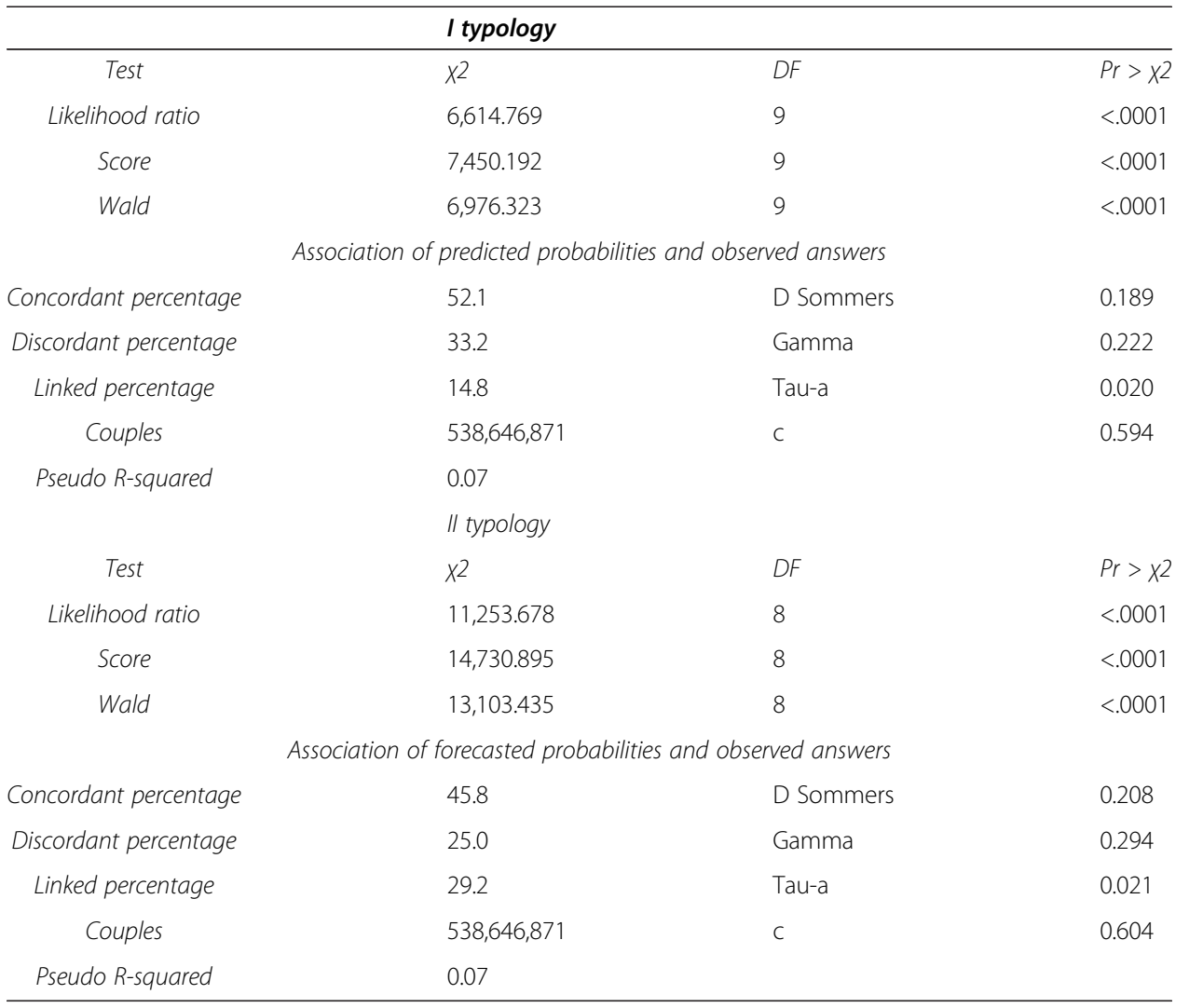

families in the mature and older phase of the life cycle have a lower probability to exploit policy opportunities.

The logistic model applied to the second type of family farms gives other interesting insights, due to the presence of an assistant (Tables 8 and 9). If, on the one hand, young farmers confirm their aptitude to obtain funds for rural development, on the other side, the presence of an assistant partially modifies the picture. An assistant prevailingly or exclusively employed to support farming activity gives the farm higher opportunities of being funded. Moreover, in the case of negative estimates, the presence of prevalent or

Table 6 Logistic regression for the first demographic typology

\begin{tabular}{cllll}
\hline & Estimation & Standard error & X2 Wald & $\operatorname{Pr}>\boldsymbol{X} \mathbf{2}$ \\
\hline Intercept & -2.7072 & 0.0218 & 15404.318 & $<.0001$ \\
Only farmer Y & 0.9222 & 0.0654 & 199.0056 & $<.0001$ \\
Only farmer M & -0.0233 & 0.0370 & 0.3949 & 0.5298 \\
Only farmer O & -0.3198 & 0.0436 & 53.8447 & $<.0001$ \\
Childless couple Y & 0.3917 & 0.1090 & 12.9005 & 0.0003 \\
Childless couple M & -0.4442 & 0.0390 & 129.9321 & $<.0001$ \\
Childless couple O & -0.7035 & 0.0522 & 181.4673 & $<.0001$ \\
Couple with children Y & 0.5717 & 0.1026 & 31.0505 & $<.0001$ \\
Couple with children M & -0.1534 & 0.0349 & 19.2762 & $<.0001$ \\
Couple with children A & -0.5084 & 0.0786 & 41.8620 & $<.0001$ \\
\hline
\end{tabular}


Table 7 Odd ratio (vs extended families)

\begin{tabular}{cc}
\hline & Estimation \\
\hline Only farmer Y & 1.925 \\
Only farmer M & 0.748 \\
Only farmer O & 0.556 \\
Childless couple Y & 1.133 \\
Childless couple M & 0.491 \\
Childless couple O & 0.379 \\
Couple with children Y & 1.356 \\
Couple with children M & 0.657 \\
Couple with children A & 0.460 \\
\hline
\end{tabular}

exclusive assistants reduces the negative effect on the access to rural development policies. Table 9 makes this well-rendered. Firstly, the transition towards older steps of the life cycle induces a reduction in the probability to obtain funds. Secondly, it confirms the importance of a prevalent or exclusive presence of assistants in farming activity.

The comparison between the two methodologies of classification of family farms has revealed its utility: in fact, discriminating the presence of assistants is a relevant factor in stimulating the ability of consuming policy. The next paragraph details the main measures used by farms.

\section{The consumed measures}

In this paragraph we will detail the consumption of rural development policies by articulating them on the basis of the three strategic axes. The synthetic results are presented in Table 10, while in the following tables the same results are distinguished by family farm typology.

The lowest share of funded farms concerns the incentives for farm diversification (third axis): here the percentage of farms is less than $1 \%$. In the first axis the level of adoption is very low and involves $2.4 \%$ of total farms (Table 10), while the rate of access to the measure included in the second axis is higher (3.4\%).

The high costs of using European policies, in terms of bureaucracy, transaction costs, etc. could be a first motivation to explain low rates of access. On the other side, the

Table 8 Logistic regression for the second demographic typology

\begin{tabular}{cllll}
\hline & Estimation & Standard error & X2 Wald & Pr > X2 \\
\hline Intercept & -25.083 & 0.0277 & 8216.9520 & $<.0001$ \\
Young farmer and a not young assistant p/e & 1.0126 & 0.0575 & 309.6402 & $<.0001$ \\
Young farmer and a not young assistant np & 0.4760 & 0.1060 & 20.1646 & $<.0001$ \\
$\quad$ Young farmer without assistant & 0.4647 & 0.0426 & 119.2140 & $<.0001$ \\
Mature farmer and a young assistant p/e & -0.0131 & 0.0545 & 0.0576 & 0.8104 \\
Mature farmer and a young assistant np & -0.4103 & 0.0910 & 20.3114 & $<.0001$ \\
$\quad$ Mature farmer without assistant & -0.4692 & 0.0336 & 195.4155 & $<.0001$ \\
Older farmer and a young assistant p/e & -0.1603 & 0.1022 & 2.4610 & 0.1167 \\
Older farmer and a young assistant np & -0.1931 & 0.1208 & 2.5544 & 0.1100 \\
\hline
\end{tabular}


Table 9 Odd ratio (vs extended families)

\begin{tabular}{ll}
\hline Odd ratio (vs older farmer without assistant) & Estimation \\
\hline Young farmer and a not young assistant p/e & 5.584 \\
Young farmer and a not young assistant $n p$ & 3.266 \\
$\quad$ Young farmer without assistant & 3.229 \\
Mature farmer and a young assistant p/e & 2.002 \\
Mature farmer and a young assistant np & 1.346 \\
Mature farmer without assistant & 1.269 \\
Older farmer and a young assistant p/e & 1.728 \\
Older farmer and a young assistant np & 1.672 \\
\hline
\end{tabular}

low share of access is particularly relevant in the case of $3^{\text {rd }}$ axis, which contains new tools for sustaining quality of life and economic diversification in rural areas ${ }^{8}$.

A detailed consumption of policies is illustrated in Table 11: the table clearly discriminates young versus older families: policies falling in the first axis are generally consumed by young farms; besides, when young farmers have an assistant the aptitude to invest is systematically higher (6 percentage points);

Elderly families prevailingly consume measures under the second axis, which are exclusively related to environmental payments ${ }^{9}$. Finally, the table points out a very low percentage of farms having used measures of quality of life and diversification of rural economy ( $3^{\text {rd }}$ axis). However, even in this case, the second type of family farms located in younger phases display a higher percentage of access, thanks to the presence of an active assistant.

\section{Conclusions}

The paper aimed at showing the relevance of demographic factors in influencing the way family farms gain access to funds for rural development. The demographic perspective has been introduced through two typologies of classification of family farms. Empirical analysis has shown important insights:

- first of all, a reduced share of consumption of rural policy emerges, above all in terms of new tools foreseen within the third axis of the rural development programme;

- a second element of reflection stems from the consideration of demographic variables: family farms managed by a young entrepreneur demonstrate a higher probability to obtain funds, thanks to a longer life expectancy, which raises farmers' alertness and his propensity to invest;

- finally, the two adopted demographic perspectives confirm the importance of the assistants, above all exclusive or prevalent, in taking investment decisions and

Table 10 Rate of access to rural development policies

\begin{tabular}{lll}
\hline & n. farms & \% on total farms \\
\hline axis 1 & 2,463 & 2.4 \\
axis 2 & 3,479 & 3.4 \\
axis 3 & 101 & 0.1 \\
\hline
\end{tabular}


Table 11 Consumption of rural development policies (\%)

\begin{tabular}{llll}
\hline & I axis & II axis & III axis \\
\hline Only farmer Y & 9.5 & 6.5 & 0.3 \\
Only farmer M & 23.3 & 3.6 & 0.1 \\
Only farmer O & 2.1 & 2.7 & 0.0 \\
Childless couple Y & 6.0 & 3.5 & 0.0 \\
Childless couple M & 1.6 & 2.8 & 0.1 \\
Childless couple O & 1.1 & 2.3 & 0.0 \\
Couple with children Y & 5.6 & 6.5 & 0.1 \\
Couple with children M & 2.1 & 3.7 & 0.1 \\
Couple with children O & 1.1 & 3.0 & 0.1 \\
Extended families and other & 4.0 & 4.7 & 0.2 \\
\hline & I axis & II axis & III axis \\
\hline Young farmer and a not young assistant p/e & 12.6 & 7.7 & 0.7 \\
Young farmer and a not young assistant $n p$ & 7.3 & 5.7 & 0.6 \\
Young farmer without assistant & 7.0 & 5.7 & 0.4 \\
Mature farmer and a young assistant p/e & 3.0 & 4.9 & 0.2 \\
Mature farmer and a young assistant $n p$ & 1.8 & 3.6 & 0.0 \\
Mature farmer without assistant & 1.9 & 3.3 & 0.1 \\
Older farmer and a young assistant ple & 3.1 & 4.1 & 0.2 \\
Older farmer and a young assistant $n p$ & 2.1 & 4.4 & 0.0 \\
Older farmer without assistant & 1.5 & 2.6 & 0.0 \\
\hline
\end{tabular}

obtaining access to rural policies to sustain farm adjustment. The lower level of access registered in the first typology of farms emphasises the relevance of the present/absent assistant farmer, recently underlined in literature on the subject (Koutsou et al. 2011).

According to the neo-Austrian perspective adopted by this paper, it is possible to sustain the hypothesis that the family farm's alertness is significantly higher in the case of either young farms or young farms where assistants support the farmer's activity, above all in the early stages of life cycle. However, the explanation for the ability of young farmers of obtaining funds from rural development policies cannot overlook the fact that the subjective condition of a "young farmer" is a priority in the allocation of resources for rural development. There is also a specific measure for the settlement of young farmers and an implicit resource reservation. On the other side, that means that "targetisation" works well in improving generational renewal. In this perspective, the introduction of a demographic viewpoint has given important insights, in order to fully understand the decision making mechanism to consume rural policies. The differences due to the two adopted demographic perspectives support the necessity to discriminate the supply of policy by taking these factors into account. More precisely, the discovered impact of the presence of family members working as assistants should encourage policies to foster their permanence in the farm and to avoid the search of off-farm jobs. Surely, rural development policies aimed at encouraging a farm's boundary shift (Banks et al. 2002) are in the agenda, but they are not exploited enough, owing to a set of motivations well described in other studies on the subject. To this end, more efforts are 
necessary to increase the percentage of access and, through this, raise the probability of higher levels of persistency of family farms.

\section{Endnotes}

${ }^{1}$ Families, friends and firms.

${ }^{2}$ See, among others, Rausser 1982; de Gorter and Swinnen 2002, Peltzman 1976.

${ }^{3}$ The assistant is a family member who helps the farmer.

${ }^{4}$ The average age is related to the woman, when she is present in the farm.

${ }^{5}$ Dissimilarities are eventually attributable to the presence of young members even within extended families.

${ }^{6}$ See www.istat.it for more details.

${ }^{7}$ The value is equal to 1 for farms that get access to funds and 0 for farms that do not.

${ }^{8}$ For the evaluation of policy consumption under Axis 3 it is necessary to precise that a part (often considerable) of the resources allocated to this axis is not devoted to farmers, but to other entities, both public and private.

${ }^{9}$ See the data concerning the progress of the spending on www.reterurale.it.

Competing interests

Both authors declare that they have no competing interests.

Authors' contributions

LB and MDR prepared the data, performed the statistical analysis, drafted, read and approved the final manuscript together.

\section{Acknowledgements}

This research was conducted with support from the Region Lazio, Department of Agriculture and Rural Development. We would like to thank Roberto Aleandri, Stefano Risa, Laura Baldini, Manuela Corleto (Region Lazio) and the anonymous reviewers for helpful comments and suggestions on an earlier version of the manuscript.

Received: 25 October 2012 Accepted: 3 October 2013

Published: 14 Oct 2013

References

Abdel HT (1997) Accumulation productive dans l'agriculture familiale : origines et modalités. Options Méditerranéennes 12:151-165

Abdelmalek AA (2000) L'exploitation familiale agricole: entre permanence et évolution. Ėconomie Rurale 255-256:40-52

Albisser G, Lehmann B (2007) Agent-based modelling of structural change in agriculture: experiences from the implementation of cooperation and collaboration. $103^{\text {rd }}$ EAAE seminar. Adding value to the agrofood supply chain in the future Euromediterranean space, Barcelona, Spain, April 23rd - 25rd

Balmann A (1997) Farm-based modelling of regional structural change. European Review of Agricultural Economics 25 (1):85-108

Balmann A, Happe K, Kellermann K, Kleingarn A (2003) Adjustment costs of agri-environmental policy switchings: a multi-agent approach. In: Janssen MA (ed) Complexity and ecosystem management: the theory and practice of multi-agent approaches. Mass., Edward Elgar Publishers, Northampton

Banks A, Long J, van der Ploeg JD (eds) (2002) Living Countrysides: Rural Development Processes in Europe - The State of the Art. Elsevier, Doetinchem

Bartoli L, De Rosa M (2011) L'adoption des politiques pour le développement agricole et rural dans les systèmes territoriaux italiens. Revue d'économie régionale et urbaine 3:601-624

Bartoli L, De Rosa M (2007) Différenciation typologique entre familles agricole set fermes dans l'agriculture italienne. New Medit 1:36-45

Becker G (1983) A theory of competition among pressure groups for political influence. Q J Econ 3:371-400

Ben-Porath Y (1980) The F-connection: family, friend and firm, and the organization of exchange. Population and Development review 6(1):1-30

Berger T (2001) Agent-based spatial models applied to agriculture: a simulation tool for technology diffusion, resource use changes and policy analysis. Agricultural Economics 25(2):245-260

Bergstrom T (1996) Economics in a family way. Journal of Economic Literature 34(4):1903-1934

Burton R (2004) Seeing through the 'good farmer's' eyes: towards developing an understanding of the social symbolic value of 'productivist' behavior. Sociologia Ruralis 44(2):195-215

Caillavet F, Facchini F, Moreddu C (2005) Introduction. Économie Rurale 289-290:7-9 
Casieri A, Nazzaro C, Roselli L (2010) Trust building and social capital as development policy tools in rural areas. An empirical analysis: the case of the LAG CDNISAT. New Medit. Mediterranean Journal of Economics, Agriculture and Environment, IX(1):24-30

Corsi A (2009) Family farm succession and specific knowledge in Italy. Rivista di Economia Agraria LXIV(1-2):13-29

Darnhofer I (2010) Strategies of family farms to strengthen their resilience. Environmental Policy and Governance 20 (4):212-222

de Gorter H, Swinnen J (2002) Political Economy of Agricultural Policy. In: Gardner B, Rausser G (eds) Handbook of Agricultural Economics vol. 2. Elsevier, Amsterdam

Downs A (1957) An economic theory of democracy. Harper and Row, New York

Errington A, Gasson R (1993) The farm family business. Cab International, Wallingford

Gasson R, Crow G, Errington A, Hutson J, Marsden T, Winter DM (1988) The farm as a family business: a review. Journal of Agricultural Economics 39(1):1-41

Happe K (2004) Agricultural policies and farm structures - Agent-based modelling and application to EU-policy reform. In: Studies on the Agricultural and Food Sector in Central and Eastern Europe vol. 30, Halle (Saale). , , http://www. iamo.de/dok/sr_vol30.pdf accessed on: 05.04.2011

Jervell AM (2011) The family farm as a premise for entrepreneurship. In: Alsos GA, Carter S, Ljunggreen E, Welter F (eds) Handbook of research on entrepreneurship in agriculture and rural development. Elgar, Cheltenham

Jervell AM (1999) Changing Patterns of Family Farming and Pluriactivity. Sociologia Ruralis 39(1):110-116

Kirzner IM (1973) Competition and entrepreneurship. University of Chicago Press, Chicago

Kirzner IM (1997) Entrepreneurial discovery and the competitive market process: an Austrian approach. Journal of Economic Literature XXXV:60-85

Knoke D, Burke P (1980) Log Linear Models. Sage, Beverly Hills, CA

Koutsou S, Partalidou M, Petrou M (2011) Present or absent farm heads ? A contemporary reading of family farming in Greece. Sociologia Ruralis 51(4):404-419

Kuehne G (2012) My decision to sell the family farm. Agriculture and Human Values September::1-11. doi:10.1007/ s10460-012-9393-7

Kuehne G, Bjornlund H, Loch A (2010) Why do farmers make non-profit decision? RIRDC Publication, Australia Marotta G (2007) Consumo di politiche e prospettive delle aree rurali in Campania. In: Falessi A, Galietta M, Marotta G (eds) Consumo di politiche e prospettive delle aree rurali nel Mezzogiono d'Italia. Milano, F.Angeli

Meert $H$, van Huylenbroeck VT, Bourgeois M, van Hecke E (2005) Farm household survival strategies and diversification on marginal farms. Journal of Rural Studies 21(1):81-97

Offutt S (2002) The future of farm policy analysis: a household perspective. American Journal of Agricultural Economics 84(5):1189-1200

Olson M (1965) The logic of collective action: public goods and the theory of groups. Harvard University Press, Cambridge

Peltzman S (1976) Toward a more general theory of regulation. Journal of Law and Economics 19(2):211-240

Pollack RA (1985) A Transaction Cost Approach to Families and Households. Journal of Economic Literature 23(2):581608

Rausser GC (1982) Political economic markets: PERTs and PESTs in food and agriculture. American Journal of Agricultural Economics 64(5):821-833

Sabbatini M (ed) (2011) Pressione socioeconomica e strategie emergenti delle aziende agricole. F.Angeli, Milano

Sabbatini M (2008) Competitività e strategie emergenti delle imprese agricole. In: Boggia A, Martino G (eds) Agricoltura e mercati in transizione. Proceedings of the XLIII congress of SIDEA, Assisi, 7-9 September 2006

Van der Ploeg JD, Marsden T (eds) (2008) Unfolding webs. Assen, Van Gorcum

Whatmore SJ (1994) Farm Household Strategies and Styles of Farming: Assessing the Utility of Farm Typologies. In: Ploeg JDVD, Long A (eds) Born from Within: Practice and Perspectives of Endogenous Rural Development Assen Royal van Gorcum

10.1186/2193-7532-1-12

Cite this article as: Bartoli and De Rosa: Family farm business and access to rural development polices: a demographic perspective. Agricultural and Food Economics 2013, 1:12

\section{Submit your manuscript to a SpringerOpen ${ }^{\circ}$ journal and benefit from:}

- Convenient online submission

- Rigorous peer review

- Immediate publication on acceptance

- Open access: articles freely available online

- High visibility within the field

- Retaining the copyright to your article

Submit your next manuscript at $\boldsymbol{\nabla}$ springeropen.com 